\title{
Analysis of the Impact of the Assumed Moment of Meeting Total Energy Demand on the Profitability of Photovoltaic Installations for Households in Poland
}

\author{
Natalia Iwaszczuk (D) and Mariusz Trela *(D) \\ Faculty of Management, AGH University of Science and Technology, 30-059 Cracow, Poland; \\ niwaszcz@zarz.agh.edu.pl \\ * Correspondence: mtrela@zarz.agh.edu.pl; Tel.: +48-12-617-42-23
}

check for

updates

Citation: Iwaszczuk, N.; Trela, M.

Analysis of the Impact of the

Assumed Moment of Meeting Total

Energy Demand on the Profitability

of Photovoltaic Installations for

Households in Poland. Energies 2021,

14, 1637. https://doi.org/10.3390/

en14061637

Academic Editor: Jesús

Manuel Riquelme-Santos

Received: 2 February 2021

Accepted: 10 March 2021

Published: 15 March 2021

Publisher's Note: MDPI stays neutral with regard to jurisdictional claims in published maps and institutional affiliations.

Copyright: (C) 2021 by the authors Licensee MDPI, Basel, Switzerland. This article is an open access article distributed under the terms and conditions of the Creative Commons Attribution (CC BY) license (https:// creativecommons.org/licenses/by/ $4.0 /)$.
Abstract: In this article, the authors analyzed two extreme investment variants considering the installed capacity of Poland's residential pv installation: (a) pv installation meets electricity demand only in the first year of operation, and in each subsequent year it is necessary to purchase electricity at market prices; (b) installation meets electricity demand even in the last year of operation, and in each previous year, the excess of generated electricity needs to be transferred back to the grid, with the limited (by law) right of drawing it from the grid for free in the future. In the article, a sensitivity analysis was performed, and profitability changes were established based on the NPV value, depending on case (a) or (b). The performed analyses showed that the pv installation profitability should not be analyzed, assuming only one moment when it meets $100 \%$ of the household's electricity demand. It was shown that the choice of such a moment, depending on the value of particular technical and financial parameters, can lead to a change in the NPV value, even over $10 \%$. Although the studies were done for Poland, such an approach can be implemented in other countries.

Keywords: renewable sources of energy; photovoltaic (pv) installation; installation capacity; investment profitability analysis; program My Electricity; net present value (NPV)

\section{Introduction}

Electricity generation from photovoltaic installations is a popular way of producing energy from renewable energy sources. This applies to commercial photovoltaic farms and residential installations where the main goal is to lower electricity bills.

In the European Union, approximately $35 \%$ of electricity comes from renewable energy sources, with solar photovoltaic panels placed third among all renewable sources [1] with a $12 \%$ share. Solar electricity generation from this source allows the avoidance of the emission of pollutants produced during the burning of fossil fuels, like coal or natural gas.

In Poland, energy production is based primarily on bituminous and lignite coal, constituting $68 \%$ [2] of the total electricity production. Therefore, the development of renewable energy sources, including pv installations, is particularly beneficial (from an environmental standpoint). For the photovoltaic investment to be financially justified, it is necessary to consider numerous factors, primarily: the price of electricity, historical electricity usage, the limitations resulting from the rules and regulations (e.g., the percentage share of free electricity drawn from the grid as compared to the amount of electricity transferred to the grid) and others.

The price of electricity for households in Poland has maintained an upward trend since 2001, as shown on Figure 1. 


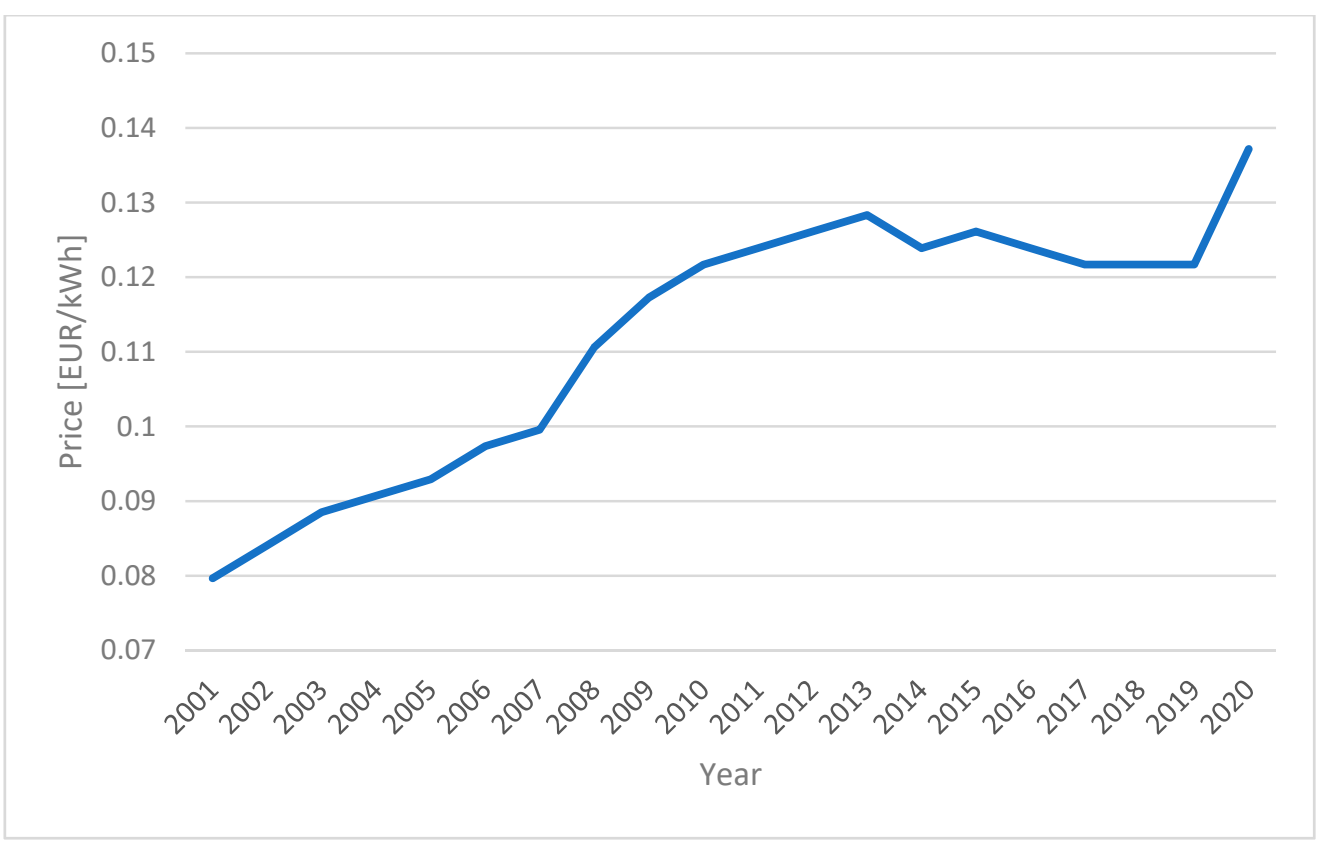

Figure 1. Average energy price for residential customers. Source: [3].

Between 2001 and 2020, the average annual increase in energy prices was 2.9\%, and the forecast for 2021 is for a $3.5 \%$ increase compared to 2020 [4].

When estimating investment profitability, the important issue is the ability to utilize support systems for the institutional investors (producing electricity with the intent of selling it) and the residential customers (households). It is possible for the residential customers to obtain a photovoltaic installation subsidy either at the central (federal) or the local level with a caveat that, most often, taking advantage of one form of the subsidy prohibits simultaneous use of the other form. The amount of support at the local level depends on the decision of local authorities. For example, in Krakow or Warsaw, residential customers may obtain up to EUR 3319. However, in Gdansk, as in many other cities, it is not possible to obtain subsidies at the local level.

Given the significant differences among the terms of local support, to maintain the option of applying the design solution suggested in the article to all residential customers in Poland using the same rules, the analyses were performed based on the central support level. This support is the result of the "Mój Prąd" [5] ("My Electricity") program and the so-called thermo-modernization rebate [6], which assumes that the investor is the entity defined in Polish legislation [7] as a "prosumer".

A prosumer is an end-user of energy produced in his own micro pv installation (with a capacity not exceeding $50 \mathrm{~kW}$ ). The prosumer reconciles an account with the energy seller on the basis of net metering, i.e., he pays only for the part of energy drawn from the grid that has not been balanced with energy produced by the household and transferred to the grid. The amount of energy produced by a pv installation varies depending on the time of year and the time of day. Household energy demand also changes throughout the day as well as each and every day. Therefore, every day there can be a difference between demand and energy production from the pv installation. The main source of energy for the household is the energy produced by its own pv installation. If the amount of energy produced is greater than the demand, the surplus energy is transferred to the electricity grid. Conversely, the shortfall of energy is provided by the grid.

When reconciling the account between the prosumer and the grid, the total amount of energy transferred to the grid is compared to the total amount of energy drawn from the grid. The settlement is done on an annual basis ( 365 days), and when calculating the amount of energy transferred to the grid, the following ratios are used:

- $\quad 0.8$ - for pv installations up to $10 \mathrm{~kW}$ capacity; 
- $\quad 0.7$-for pv installations with a capacity above $10 \mathrm{~kW}$.

Thus, if the prosumer in a given year consumed more energy than he supplied (taking into account this ratio), he is obliged to pay for each unit of energy according to the standard price list. If the prosumer transferred more energy to the grid than he consumed (taking this ratio into account), he does not incur any costs of purchasing energy, but he also does not receive any compensation for the surplus energy transferred to the grid.

\section{State of the Art}

Publications related to electricity production using solar energy are very often dedicated to the subject of photovoltaic farms. Many aspects associated with their operations are analyzed, both technical and financial, as well as environmental. Regarding the technical aspects, the researchers have analyzed, for example, the impact of photovoltaics on power quality [8], the efficiency of different types of photovoltaic cells [9], or the efficiency of different components of a pv system [10]. In the financial context, the researchers examine the opportunities to reduce the cost of energy [11], calculate the operating and capital costs of different solutions to optimize the sizing of dispersed energy resources [12], or analyze the costs of pv systems using energy storage [13]. As far as the environmental issues are concerned, some publications present a general approach to power engineering, indicating the necessity for a transition from fossil fuels to renewable energy sources [14], while others analyze in detail the pollutant emissions using appropriate indicators [15] or using the Life Cycle Analysis (LCA) method [16]. Profitability issues associated with such investments are also often analyzed. In the case of photovoltaic farms, the conclusions regarding investment profitability are most often reached based on the measurements such as Net Present Value (NPV), Internal Rate of Return (IRR), Payback Period (PBP), or Levelized Cost of Energy (LCOE). This is demonstrated by many publications, both referring to cost-effectiveness analyses of pv installations located in the USA [17], the EU [18], and other regions of the world [19]. At times, the analyses also take into consideration the social costs and are performed in a wider context, using methods such as Life Cycle Cost (LCC) or Cost-Benefit Analysis (CBA). The LCC method has been used to study the economic feasibility of investing in pv panels in Jordan [20] and Malaysia [21]. The method has also been applied in the process of optimizing the size of pv installations [22]. The CBA method, on the other hand, has been used to compare a pv installation with an alternative natural gas power generation installation [23] and also in the context of demonstrating the economic viability of a pv installation in Kuwait [24].

Profitability calculations for residential installations are less complicated since they do not consider amortization, taxes, and the cost of purchasing or leasing land. It is also much simpler to analyze the sources of investment financing, which are very often limited to the owner's equity and a form of a government subsidy set up for the residential customers at the central or local level. Moreover, most often, the photovoltaic investment profitability is not compared to the alternate investment projects' profitability. In such cases, to estimate the profit from the investment project, most often, the NPV value is being analyzed. This method is used successfully in similar studies conducted around the world. It proves to be effective for analyses of support systems for pv installations [25], as well as for variant comparisons of the profitability of pv installations [26]. It is also applicable in cross-sectional studies conducted on a very large number of cases [27].

Often, the purpose of a publication is to propose a design solution optimizing the operation or the construction of a photovoltaic farm. This optimization may apply to the parameters of the photovoltaic modules [28], the location of the pv installation [29], or the way the produced energy is used [30]. Thus, it often takes the form of determining the appropriate installation parameters for a given site so that a predetermined amount of energy production can be achieved or indicates the parameters defining the way this energy is used. The approach is similar to the analyses done for the residential photovoltaic installations [31]. However, in this case, energy self-consumption is important for the profitability of the investment. Studies in this area more and more often address energy 
storage issues [32] and take into account increasingly detailed parameters such as hourly energy demand or hourly energy production [33].

The studies conducted for Poland were also focused on analyzing the influence of individual, sometimes very specific, factors on the amount of generated electricity. The effect of dust on the performance of the pv panels has been studied [34], as well as shading and misalignment of modules [35]. Furthermore, attempts are made to generalize the approach to the issue of the pv panels' investment profitability for residential customers in Poland, where an analysis was performed examining the influence of the changes in the individual factors on the NPV value for a defined initial amount of electricity production [36].

Moreover, studies were conducted analyzing the impact of meteorological data on electricity production forecasting [37]. Studies were also conducted on more technologically advanced pv systems, with the ability to store generated electricity [38] or the systems based on photovoltaic roof tiles [39].

However, the analyses focus primarily on considering individual parameters that impact the amount of electricity produced and, as such, on the profitability of the entire pv installation. From a user's point of view, such studies provide an insight of how the value of each individual parameter and/or the applied technology influences the amount of electricity produced. However, they preclude the ability to establish the optimal amount of electricity that has to be produced in the first year of operation of the pv panels and this is the basis for determining the capacity of the installation.

Profitability analyses of the pv installations are very often performed in such a way that a specific installation capacity is assumed, and subsequently, the energy production and potential return on investment are estimated, depending on various parameters. According to this assumption, analyses are made for the pv installations situated all over the world, such as those in Japan [40], India [41], or Germany [42]. Analogical analyses have also been performed for the pv installations located in Poland, both for commercial photovoltaic farms [43] and residential installations [44]. However, it is possible to perform a cost-effectiveness analysis, taking into account what was previously calculated and appropriately adjusted for a given installation capacity of the photovoltaic system. The installation's capacity in such a situation is very often calculated according to the assumption that it should be selected in such a way that maximum use is made of the energy produced by the pv panels and the necessary minimum is purchased from the grid [45]. A similar assumption referring to the necessity of a complete balancing of the energy produced and drawn from the grid was presented in the conclusions of an analysis concerning a pv installation for a household in Poland [46]. However, in formulating these assumptions, it was not indicated in which year of the system operation the full balancing should occur. This is an important issue because due to the pv panels' degradation, energy production decreases every year. Therefore, determining the year in which such balancing should occur can change the NPV of the entire investment. Therefore, this paper uses a modified approach to analyze the profitability of pv installations, extending the analyses conducted so far with a parameter specifying the year in which the household's total energy demand will be met.

\section{Research Problem}

Over time, all photovoltaic panels lose their ability to produce electricity from a unit of power (their efficiency decreases). Consequently, while choosing the installation's size, different approaches can be used to meet the individual household's total electricity demand. This means that the investment profitability will change depending on the choice of the financial model used.

In this article, two extreme approaches will be analyzed, where the residential installation meets $100 \%$ of electricity demand:

- in the first year of operation, and in every subsequent year, the missing electricity is purchased from the grid (at normal prices); 
- in the last year of operation and in previous years, the surpluses of electricity are too big for the possibility of utilizing them based on the rules pertaining to the prosumers.

This article's goal is to establish profitability changes of the investment in the residential photovoltaic installation, depending on the moment of complete coverage of electricity demand, while considering the chosen technical and market parameters. It was assumed in the article that a complete electricity demand coverage takes place when the electricity generated by a photovoltaic installation meets $100 \%$ of the electricity demand of a given household, based on the regulations applicable to the prosumers in Poland.

\section{Study Method and Data Input}

Implementation of the abovementioned goal was done using the study approach presented in Figure 2.

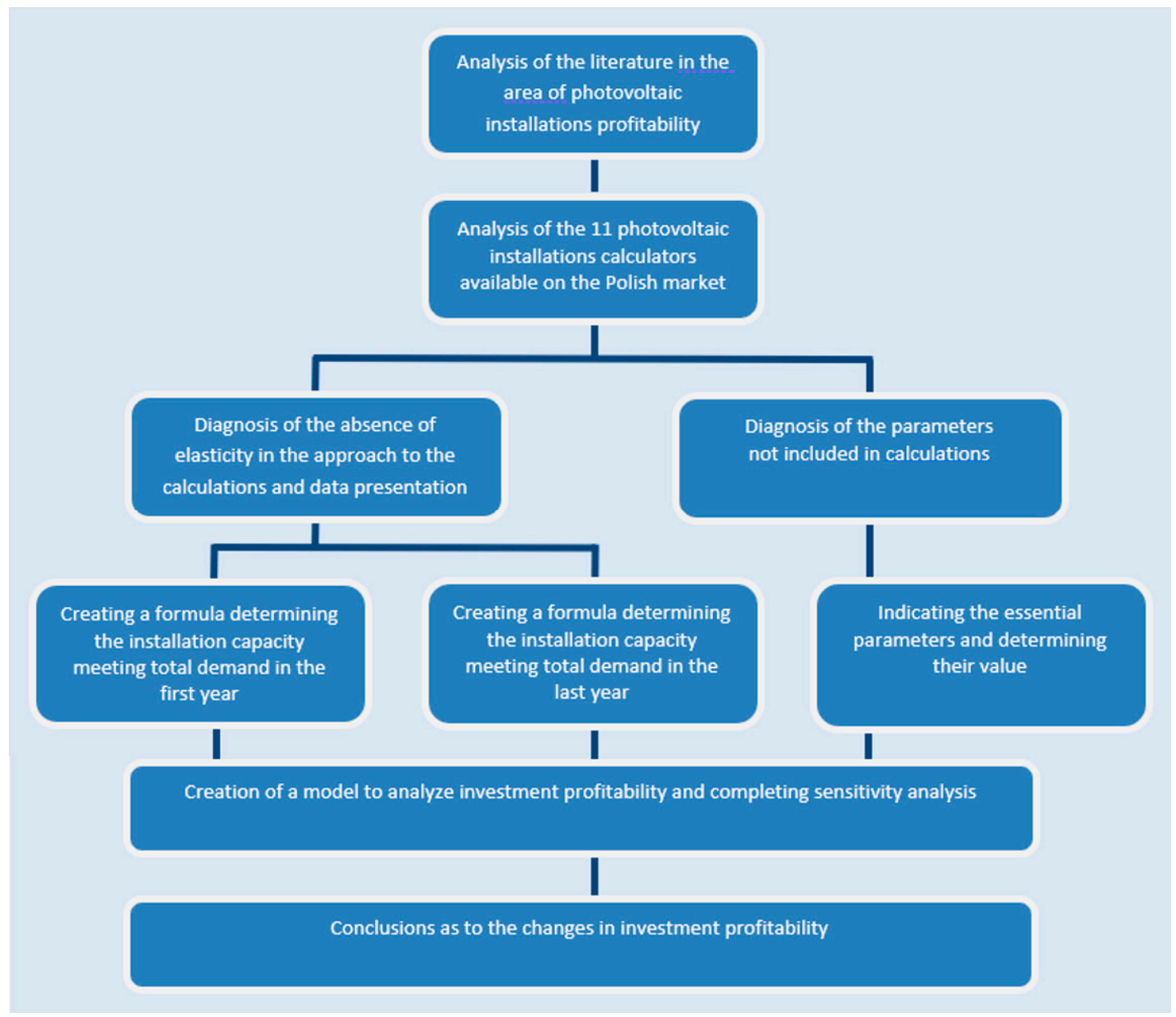

Figure 2. The study approach applied in the article. Source: own study.

Analyzing the literature on photovoltaic installations' profitability provided a basis to test the performance of the internet calculators in determining the installation capacity and/or profitability of the investment in the photovoltaic panels by Polish residential customers.

These calculators are being created at the European Union and individual country level. The calculator posted on the European Commission webpage [47] provides access to maps and solar irradiance data in particular parts of the world and, based on that, calculates the amount of electricity that can be produced. It is a helpful tool to obtain some parameter values, but it cannot determine the optimal installation capacity for a prosumer in Poland. This results from the calculator's construction and the legislative provisions 
(for this area) in Poland. Similarly, the calculators created in other countries $[48,49]$ do not take into account Polish legislative particularities with regard to the prosumer, so their usefulness is very limited.

From the point of view of the Polish investor, the most accurate are the calculators dedicated to Poland. Based on the research [50], the paper analyzed 11 online calculators (listed in [51-61] References), considered to be the most popular in Poland. The analyses made it possible to draw the following conclusions:

1. There is no option in any of the calculators to choose the moment when the photovoltaic installation meets 100\% of electricity demand; none of the calculators indicate the year when such coverage takes place. Based on the financial analyses, it is impossible to establish unequivocally in which year the $100 \%$ coverage will take place. Due to the lack of any information in this regard (both at the stage of data entry and presentation of the results), it can be assumed that all calculators have an established permanent moment of $100 \%$ of electricity demand coverage.

2. None of the calculators present the data so that it would be possible to verify singlehandedly the accuracy of the calculations and determine the assumptions that are crucial to the calculations.

3. It needs to be assumed that none of the calculators perform the calculations using a discount rate. Due to the lack of the ability to introduce discount rate value and, at the same time, the lack of presentation of its implied value in the entire calculation process, it is possible to assume that all calculators omit discount rate in the calculations.

4. It needs to be assumed that none of the calculators perform the calculations, assuming a replacement of the inverter for a new one during the operation of the photovoltaic installation. Due to the lack of the ability to introduce the number of inverter replacements during the operation of the pv installation and the lack of representation of an implied value determining it, it was presumed that all calculators assume the functioning of one inverter throughout the entire time of operation of the pv installation.

5. One of the analyzed calculators is a commercial program offered to pv installation retailers. It is not dedicated to residential consumers wanting to perform profitability and the photovoltaic installation assembly calculations; therefore, the conclusions were formulated with the omission of evaluating this calculator. Based on the analysis (based on the example of the report posted on the program producer's webpage), it can be concluded that the calculator does not consider changes in the value of money in time because the discount value is not indicated (or required to be inputted). Additionally, in the table defining cash flows, there is no term "discounted cash flows" or the like, but only "cumulative cash flow." In reference to this calculator (based on the posted report) it is impossible to draw conclusions in any other regard.

Based on the completed analysis and the identified shortcomings in functionality (i.e., the ability to compare the investment financial parameters depending on the moment of meeting $100 \%$ of electricity demand), as well as the lack of considering market parameters crucial to the analysis, it was concluded that it was necessary to create a proprietary analytical model of the profitability of the financial investment in photovoltaic panels.

\section{Assumptions and Parameters of the Model Calculating pv Installations Profitability}

In the study, it was assumed that the model that would be used to analyze the photovoltaic installation investment profitability should consider:

1. Total electricity demand coverage by the photovoltaic panels in the last year of operation of the installation.

2. Total electricity demand coverage by the photovoltaic panels in the first year of operation of the installation.

3. The discount rate in the profitability calculation.

4. One-time replacement of the inverter during the operation of the pv installation.

5. Subsidy from the "My Electricity" program. 


\section{Thermo-modernization rebate.}

For the model to take into consideration total electricity demand coverage by the pv installation in the first and the last year of operation, it became necessary to use the formulas determining its capacity in various moments of operation. For this, the formulas were created calculating the installation capacity, which would meet $100 \%$ of electricity demand in the first (1) and the last (2) year of operation.

$$
\begin{gathered}
\mathrm{M}_{1}=\frac{\mathrm{Z}_{\mathrm{p}}}{\mathrm{K}_{\mathrm{p}}+\mathrm{K}_{\mathrm{o}} \times\left(1-\mathrm{K}_{\mathrm{p}}\right)} \times \frac{1}{\mathrm{P}_{\mathrm{r}}} \\
\mathrm{M}_{2}=\frac{\mathrm{Z}_{\mathrm{p}}-\left(1-\mathrm{K}_{\mathrm{o}}\right) \times\left(\mathrm{M}_{1} \times \mathrm{P}_{\mathrm{r}} \times \mathrm{K}_{\mathrm{p}}\right)}{\mathrm{K}_{\mathrm{o}} \times \mathrm{P}_{\mathrm{r}} \times\left(1-\left(\mathrm{O}_{\text {eks }}-1\right) \times \frac{\mathrm{q}}{100}\right)}
\end{gathered}
$$

In the model, it was assumed that the owner of the photovoltaic installation is a prosumer who, according to the Act OZE [7], may utilize the electricity produced from his or her own pv installation prior to exporting it to the power grid, and later, may draw the electricity transferred to the grid for free. The free electricity draw is $80 \%$ (in the installation where the capacity does not exceed $10 \mathrm{~kW}$ ) or $70 \%$ (in the installation where the capacity exceeds $10 \mathrm{~kW}$ ), relative to the amount of electricity transferred to the grid.

Additional assumptions:

- $\quad$ price of each installation exceeds 2212.39 EUR; therefore, the prosumer takes advantage of the "My Electricity" program subsidy, which decreases investment costs by 1106.19 EUR;

- prosumer takes advantage of the thermo-modernization rebate, decreasing taxation base by the investment value; reduced by the amount of received subsidy;

- prosumer is a personal income tax taxpayer, paying the $17 \%$ tax rate [62];

- it was assumed that the amount of money received from the subsidy would be deposited to the prosumer account as a tax refund in the second year of operation of the pv installation;

- pv installation lifetime is 25 years;

- in this lifetime, it will be necessary to perform a one-time inverter replacement, which will be done in the 15th year of the operation of the pv installation;

- electricity demand will be constant throughout the lifetime of the pv installation.

Investment profitability assessment was performed based on the current net NPV value (Net Present Value), which was based on the analysis of discounted cash flows and assumed discount rate, according to the formula (3) [63].

$$
\mathrm{NPV}=\sum_{\mathrm{t}=1}^{\mathrm{n}} \frac{\mathrm{CF}_{\mathrm{t}}}{(1+\mathrm{r})^{\mathrm{t}}}-\mathrm{I}_{\mathrm{o}}
$$

where:

$$
\begin{gathered}
C_{\mathrm{t}}=\left(\mathrm{S}_{\mathrm{et}}+\mathrm{R}_{\mathrm{t}}\right)-\left(\mathrm{C}_{\mathrm{et}}+\mathrm{A}_{\mathrm{st}}+\mathrm{C}_{\mathrm{it}}\right) \\
\mathrm{S}_{\mathrm{et}}=\mathrm{Z}_{\mathrm{p}} \times\left[\mathrm{C}_{\mathrm{kWh}} \times\left(1+\mathrm{i}_{\mathrm{e}}\right)^{\mathrm{t}}\right] \\
\mathrm{C}_{\mathrm{et}}=\mathrm{E}_{\mathrm{bt}} \times\left[\mathrm{C}_{\mathrm{kWh}} \times\left(1+\mathrm{i}_{\mathrm{e}}\right)^{\mathrm{t}}\right] \\
\mathrm{E}_{\mathrm{bt}}=\mathrm{Z}_{\mathrm{p}}-\left(\mathrm{E}_{\mathrm{ut}}+\mathrm{E}_{\mathrm{rt}}\right) \\
\mathrm{E}_{\mathrm{bt}}=\mathrm{E}_{\mathrm{pt}} \times \mathrm{K}_{\mathrm{p}} \\
\mathrm{E}_{\mathrm{rt}}=\mathrm{K}_{\mathrm{o}} \times \mathrm{E}_{\mathrm{nt}} \\
\mathrm{E}_{\mathrm{nt}}=\mathrm{E}_{\mathrm{pt}}-\mathrm{E}_{\mathrm{ut}} \\
\mathrm{E}_{\mathrm{pt}}=\left[\left(\mathrm{P}_{\mathrm{r}} \times \mathrm{M}\right) \times(1-\mathrm{t} \times \mathrm{q})\right]
\end{gathered}
$$


It was assumed that the savings resulting from the absence of the need to purchase a specified amount of electricity as well as the reimbursement resulting from the thermomodernization subsidy are positive cash flows. It was also assumed that the cost of electricity purchased from the power grid, the fixed electricity costs, and the inverter's cost are negative cash flows.

The initial capital investment $\mathrm{I}_{0}$ was determined as the difference between the pv installation cost and the value of 1106.19 EUR resulting from the "My Electricity" program subsidy.

The investment parameter base values, taken into account when calculating the NPV value, are shown in Table 1.

Table 1. Photovoltaic installation investment parameters for a residential customer.

\begin{tabular}{cc}
\hline Parameter & Value \\
\hline$C_{\text {inst. }}$ & $980 \mathrm{EUR} / \mathrm{kWp}^{1}$ \\
\hline $\mathrm{Z}_{\mathrm{p}}$ & $3006 \mathrm{kWh} /$ year $^{2}$ \\
\hline $\mathrm{P}_{\mathrm{r}}$ & $1000 \mathrm{kWh} / \mathrm{kWp}^{3}$ \\
\hline $\mathrm{C}_{\mathrm{kWh}}$ & $0.14 \mathrm{EUR} / \mathrm{kWh}^{4}$ \\
\hline $\mathrm{i}_{\mathrm{e}}$ & $2.9 \%^{5}$ \\
\hline $\mathrm{i}$ & $2.3 \%^{6}$ \\
\hline $\mathrm{q}$ & $0.7 \%{ }^{7}$ \\
\hline $\mathrm{K}_{\mathrm{o}}$ & $80 \%{ }^{8}$ \\
\hline $\mathrm{K}_{\mathrm{p}}$ & $31.6 \%{ }^{9}$ \\
\hline $\mathrm{A}_{\mathrm{st}}$ & $21 \mathrm{EUR} / \mathrm{year}^{10}$ \\
\hline $\mathrm{r}$ & $4 \%{ }^{11}$ \\
\hline $\mathrm{C}_{\mathrm{inw}}$ & $885 \mathrm{EUR}{ }^{10}$ \\
\hline
\end{tabular}

${ }^{1}$ Based on ([64], p. 20); ${ }^{2}$ based on ([65], p. 56-57); ${ }^{3}$ based on [47]; ${ }^{4}$ based on [3]; ${ }^{5}$ the energy price growth rate was assumed to be the same as for the period $2001-2020 ;^{6}$ the price increase index was assumed to be equal to the average inflation rate in Poland in the period 2001-2020; ${ }^{7}$ based on an analysis of the warranty conditions of selected manufacturers of pv panels; ${ }^{8}$ for installations up to $10 \mathrm{~kW} ;{ }^{9}$ based on ([66], p. 14); ${ }^{10}$ based on the analysis of the market offers of selected companies offering sales and installation of pv systems in Poland; ${ }^{11}$ based on ([67], p. 41)

After calculating the NPV values, an analysis was performed measuring their sensitivity to the electricity price changes. The analysis was performed for the electricity prices [EUR/kWh]: 0.12; 0.14; 0.15 and 0.16. Other parameters of the model are shown in Table 2.

The sensitivity analysis was performed in such a way that the value of one of the parameters was changed, while retaining the remaining parameters' base values. Next, a comparison was made each time between the NPV values for the investments with the capacity meeting $100 \%$ of electricity demand in the first and last year of the operation of pv installation. The results of the comparisons were presented as an excess of one value over the other one, in percentage terms. 
Table 2. The parameters and their values taken into account in the sensitivity analysis.

\begin{tabular}{|c|c|}
\hline Parameter & Value \\
\hline \multirow{3}{*}{$\mathrm{C}_{\text {inst. }}$} & $885 \mathrm{EUR} / \mathrm{kWp}$ \\
\hline & $980 \mathrm{EUR} / \mathrm{kWp}$ \\
\hline & 1150 EUR/kWp \\
\hline \multirow{3}{*}{$\mathrm{r}$} & $2 \%$ \\
\hline & $4 \%$ \\
\hline & $6 \%$ \\
\hline \multirow{2}{*}{$\mathrm{K}_{\mathrm{o}}$} & $70 \%$ \\
\hline & $80 \%$ \\
\hline \multirow{3}{*}{$\mathrm{K}_{\mathrm{p}}$} & $20 \%$ \\
\hline & $31.6 \%$ \\
\hline & $40 \%$ \\
\hline \multirow{3}{*}{ q } & $0.5 \%$ \\
\hline & $0.7 \%$ \\
\hline & $0.9 \%$ \\
\hline \multirow{4}{*}{$\mathrm{i}_{\mathrm{e}}$} & $0.5 \%$ \\
\hline & $2.9 \%$ \\
\hline & $4.5 \%$ \\
\hline & $6.5 \%$ \\
\hline
\end{tabular}

Source: own study.

\section{Study Results}

The optimal capacity of a photovoltaic installation vs. NPV index.

In the case of total electricity demand coverage in the first and the last year of operation, the optimal capacity of a photovoltaic installation, calculated based on the formulas (1) and (2) respectively, using Table 2, is:

$$
\begin{aligned}
& \mathrm{M}_{1}=3.482 \mathrm{kWp} ; \\
& \mathrm{M}_{2}=4.186 \mathrm{kWp} .
\end{aligned}
$$

The obtained results are theoretical values. In market practice, the capacity of a pv installation is a multiple of the capacity of individual pv panels, so for further calculations, it was assumed that $\mathrm{M}_{1}=3.5 \mathrm{kWp}$ and $\mathrm{M}_{2}=4.2 \mathrm{kWp}$.

The result means that the capacity will be higher by $20 \%$ for the investment parameters adopted to design an installation that meets 100\% of demand in the last year. This translates into a proportional increase in investment costs (in line with the adopted assumptions regarding the pv installation unit price). However, the prosumer's cost will ultimately increase by less than $20 \%$ due to the application of the thermo-modernization rebate, based on which a tax refund will be issued in the second year of installation.

$N P V$ values calculated for the installation capacity $M_{1}$ and $M_{2}$ are, respectively:

$$
\begin{aligned}
& \mathrm{NPV}_{1}=5380.31 \mathrm{EUR} \\
& \mathrm{NPV}_{2}=5442.04 \mathrm{EUR}
\end{aligned}
$$

The NPV value difference is approximately $1.1 \%$ to the advantage of the capacity covering the demand in the last year of operation. 


\section{Sensitivity Analysis}

The sensitivity analysis results in electricity prices at the levels [EUR/kWh]: $0.12 ; 0.14$; 0.15; 0.16 (for the parameters presented in Table 2); its results are presented in Tables 3 and 4.

Table 3. Sensitivity ratio for the NPV of the installation meeting energy demand in the first year of operation.

\begin{tabular}{|c|c|c|c|c|c|}
\hline \multirow{3}{*}{ Parameter } & \multirow{3}{*}{ Value } & \multicolumn{4}{|c|}{ Sensitivity Ratio (\%) } \\
\hline & & \multicolumn{4}{|c|}{ Price of Electricity (EUR/kWh) } \\
\hline & & 0.12 & 0.14 & 0.15 & 0.16 \\
\hline \multirow{2}{*}{$\mathrm{C}_{\text {inst }}$} & 980 & 0.0 & & & \\
\hline & 1150 & 2.5 & 0.8 & & \\
\hline \multirow{2}{*}{$\mathrm{r}$} & 4 & 0.0 & & & \\
\hline & 6 & 4.7 & 2.7 & 1.3 & 0.3 \\
\hline $\mathrm{K}_{\mathrm{o}}$ & 80 & 0.0 & & & \\
\hline \multirow{2}{*}{$\mathrm{K}_{\mathrm{p}}$} & 31,6 & 0.0 & & & \\
\hline & 40 & 3.1 & 1.7 & 0.8 & 0.0 \\
\hline \multirow{2}{*}{$\mathrm{q}$} & 0.5 & 3.8 & 2.4 & 1.4 & 0.6 \\
\hline & 0.7 & 0.0 & & & \\
\hline \multirow{2}{*}{$\mathrm{i}_{\mathrm{e}}$} & 0.5 & 6.6 & 4.0 & 2.3 & 1.1 \\
\hline & 2.9 & 0.0 & & & \\
\hline
\end{tabular}

Source: own study.

Table 4. The sensitivity ratio of the NPV for the installation meeting the energy demand in the last year of its operation.

\begin{tabular}{|c|c|c|c|c|c|}
\hline \multirow{3}{*}{ Parameter } & \multirow{3}{*}{ Value } & \multicolumn{4}{|c|}{ Sensitivity Ratio (\%) } \\
\hline & & \multicolumn{4}{|c|}{ Price of Electricity (EUR/kWh) } \\
\hline & & 0.12 & 0.14 & 0.15 & 0.16 \\
\hline \multirow{3}{*}{$\mathrm{C}_{\text {inst. }}$} & 885 & 1.1 & 2.0 & 2.7 & 3.2 \\
\hline & 980 & & 1.1 & 1.9 & 2.6 \\
\hline & 1150 & & & 0.4 & 1.3 \\
\hline \multirow{2}{*}{$\mathrm{r}$} & 2 & 3.4 & 4.1 & 4.5 & 4.9 \\
\hline & 4 & & 1.1 & 1.9 & 2.6 \\
\hline \multirow{2}{*}{$\mathrm{K}_{\mathrm{o}}$} & 70 & 10.5 & 10.9 & 11.2 & 11.4 \\
\hline & 80 & & 1.1 & 1.9 & 2.6 \\
\hline \multirow{2}{*}{$\mathrm{K}_{\mathrm{p}}$} & 20 & 4.6 & 5.4 & 5.9 & 6.4 \\
\hline & 31.6 & & 1.1 & 1.9 & 2.6 \\
\hline \multirow{2}{*}{$\mathrm{q}$} & 0.7 & & 1.1 & 1.9 & 2.6 \\
\hline & 0.9 & 2.9 & 3.8 & 4.5 & 5.0 \\
\hline \multirow{3}{*}{$\mathrm{i}_{\mathrm{e}}$} & 2.9 & & 1.1 & 1.9 & 2.6 \\
\hline & 4.5 & 2.7 & 3.4 & 3.9 & 4.3 \\
\hline & 6.5 & 5.0 & 5.4 & 5.8 & 6.0 \\
\hline
\end{tabular}

Source: own study.

The grey boxes in Table 3 indicate the same profitability of the investment, regardless of when the energy demand is met (a value of 0.0 is assumed when the difference is less than $0.05 \%)$. 
For the analyzed parameter values, the biggest NPV excess is $11.4 \%$ for the installation with the capacity covering electricity demand in the last year and $6.6 \%$ for the installation covering electricity demand in the first year of operation.

\section{Interpretation of the Results}

Based on the performed sensitivity analysis, the following conclusions can be drawn:

An increase in the price of electricity drawn from the power grid causes a decrease in the NPV value excess for the installation. Its capacity meets total electricity demand coverage in the first year of operation. This dependency is due to the fact that the increased electricity price causes an increase in positive flows in the form of savings resulting from not purchasing electricity. Simultaneously, it causes an increase in the potential cost of purchasing electricity in the case where the pv installation does not cover total electricity demand. A higher investment cost can be recovered in the form of potential future gains resulting from not purchasing electricity.

The lower unit price of a photovoltaic installation causes a reduction in the NPV value excess for the installation. Its capacity meets electricity demand coverage in the first year of operation. This dependency is due to the fact that a lower unit price translates into a lower additional cost of a pv installation, whose capacity makes it possible to meet total electricity demand coverage in the last year of operation. Therefore, the lower the additional investment cost, the higher the chance of generating a return, resulting from the savings from not purchasing electricity.

A lower discount rate causes a reduction in the NPV value excess for the installation, whose capacity meets electricity demand coverage in the first year of operation. This dependency is due to the fact that a lower discount rate results in an increased benefit to the prosumer due to the savings from not purchasing electricity in the future years of investment duration (operation of the installation).

A decrease in the ratio of utilization of electricity transferred to the grid results in an increase in the NPV value excess for the installation with the capacity to meet electricity demand in the last year of operation. This dependency is due to the fact that with a lower value of this ratio, a smaller part of the produced energy will be used for balancing, and the additional costs of drawing energy from the grid will only appear at the end of the life of the installation. On the other hand, in the case of a pv installation with a capacity meeting the demand only in the first year of its operation, the additional costs may appear from the beginning.

An increase in the ratio of electricity utilization prior to the transfer to the grid causes a reduction in the NPV value excess for the installation, whose capacity meets electricity demand coverage in the first year of operation. This dependency is explainable and is similar to the ratio of utilization of electricity transferred to the grid. The difference is that the loss of electricity is generated at an earlier stage. This means that the lower the electricity utilization before the transfer to the grid, the higher the loss (resulting from the ratio of utilization of electricity transferred to the grid) in the next stage.

A decrease in the ratio of panel degradation results in a decrease in the NPV excess for an installation with the capacity to meet electricity demand in the last year of operation. In this case, lower panel degradation only results in a higher excess of energy production over demand and does not affect the NPV. On the other hand, for a pv installation with a capacity that meets demand only in the first year of its operation, less degradation of the $\mathrm{pv}$ panels means fewer energy purchases from the grid in subsequent years and a higher NPV.

An increase in the electricity price index causes a reduction in the NPV value excess for the installation, whose capacity meets electricity demand coverage in the first year of operation. This dependency is explainable and is similar to the increase in the price of electricity transferred from the grid.

In the situation where an investor would consider building a photovoltaic installation, one should analyze many aspects associated with the technical parameters of the construc- 
tion, market-driven parameters, as well as those dependent on the utilization method of the pv installation.

Therefore, it may be concluded that the choice of the optimal utilization model of a pv installation depends on many parameters, both elective and non-elective. The first group (influenced by a user) consists of the pv installation unit price, the ratio of electricity utilization prior to the transfer, and the transfer to the grid.

On the other hand, the second group consists of (the so-called external factors) the electricity price and electricity price index, as well as the panel degradation ratio and discount rate. The user must adjust to them and, more importantly, consider them when calculating investment profitability.

\section{Conclusions}

The studies show that the photovoltaic installation profitability for residential customers is influenced by many factors, one of the most important being the way the installation capacity is calculated. In the article, the two models were analyzed: (a) the pv installation meets electricity demand only in the first year of operation, and in each subsequent year, it is necessary to purchase electricity at market prices; (b) the installation meets electricity demand even in the last year of operation, and in each previous year the excess electricity generated needs to be transferred back to the grid, without the option of utilizing it to the greatest possible, guaranteed by the law, extent.

The achieved results can be formulated in a few statements:

1. It is not possible to explicitly determine which model guarantees higher investment profitability because a higher NPV value was shown for the installation capacity meeting electricity demand coverage in the first, as well as in the last, year of operation, depending on the parameter values used in the analysis.

2. Changes in the photovoltaic investment profitability depending on the moment meeting electricity demand result primarily from the values of the following parameters:

- Price of electricity drawn from the grid by a prosumer;

- Photovoltaic installation unit price;

- Assumed discount rate;

- Ratio of electricity utilization transferred to the grid;

- Ratio of electricity utilization prior to the transfer to the grid;

- Ratio of panel degradation.

3. NPV value calculations for the base values indicated that the more profitable is the pv installation investment, the capacity of which guarantees meeting electricity demand in the first year of operation. A higher profitability of investments with the capacity to meet energy demand in the last year of operation occurs under the following conditions:

- at low discount rates,

- for lower rates of energy use before and after grid transfers,

- for higher degradation rates of pv panels.

Additionally, the increase in energy price (for each value of the analyzed parameters) increases the profitability of such investments.

The next research directions will be: analyses of the simultaneous influence of many financial and technical parameters characterizing the pv installation operating in Polish settings. This will allow drawing additional conclusions facilitating financial optimization of an investment in the prosumer's photovoltaic installation.

Author Contributions: N.I.: Development of the methodology of analyzes, conducting the literature analysis; M.T.: Conducting analyzes and drawing conclusions. All authors have read and agreed to the published version of the manuscript.

Funding: This research received no external funding.

Institutional Review Board Statement: Not applicable. 
Informed Consent Statement: Not applicable.

Data Availability Statement: The data presented in this study are available on request from the authors.

Conflicts of Interest: The authors declare no conflict of interest.

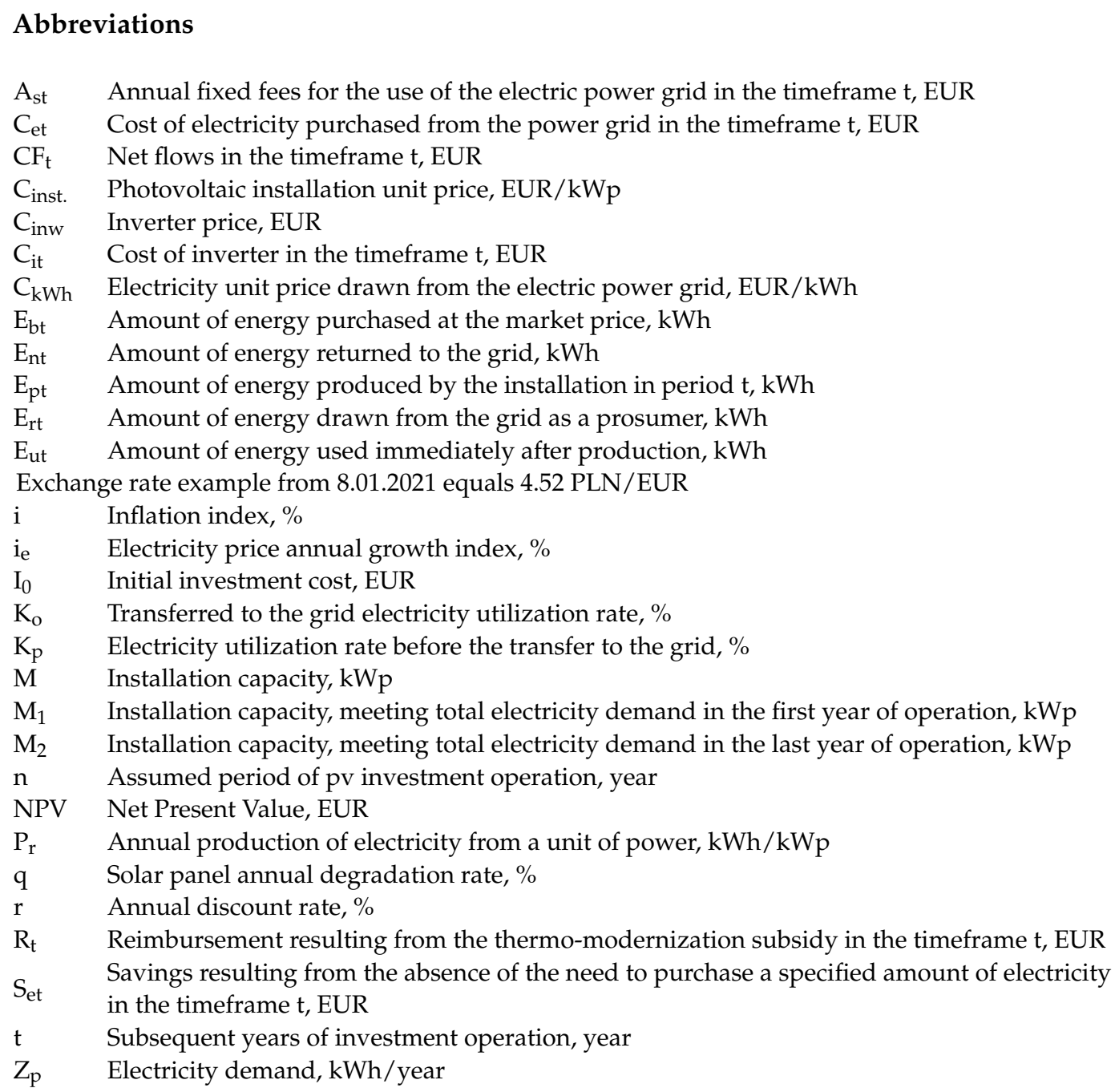

\section{References}

1. Wind and Solar Power for Electricity Generation: Significant Action Needed if EU Targets to Be Met. Available online: https: / / op.europa.eu/webpub/eca/special-reports/wind-solar-power-generation-8-2019/en/ (accessed on 12 December 2020).

2. $\quad$ Bulletin of Power Industry; No. 4 (109); Agencja Rynku Energii S.A.: Warsaw, Poland, 2019.

3. A Specialist Portal for Information on Energy Prices. Available online: www.cena-pradu.pl (accessed on 17 February 2021).

4. Energy Regulatory Office. Available online: www.ure.gov.pl (accessed on 4 January 2021).

5. Regulations of the Second Call for Funding for Projects from the National Fund for Environmental Protection and Water Management under the Priority Program “Mój Prąd”. NFOŚiGW. Warszawa 21.05.2020. Available online: https://mojprad.gov. $\mathrm{pl} /$ (accessed on 20 November 2020).

6. The Act of 26 July 1991 on Personal Income Tax. art. 26h. Version from 1 December 2020 to 31 December 2020. J. Laws Pol. 2020, 1426, 1-370.

7. The Act of February 20, 2015 on renewable energy sources. J. Laws Pol. 2015, 478, 1-231.

8. Grycan, W.; Brusilowicz, B.; Kupaj, M. Photovoltaic farm impact on parameters of power quality and the current legislation. Sol. Energy 2018, 165, 189-198. [CrossRef]

9. Lutfu, S.; Figen, B. Single junction photovoltaic cell and sub-modules in optimization of solar farms. Procedia Comput. Sci. 2019, 158, 466-473. 
10. Mondol, J.D.; Yohanis, Y.G.; Smyth, M.; Norton, B. Performance analysis of a grid-connected building integrated photovoltaic system. In Proceedings of the ISES 2003: ISES Solar World Congress 2003: Solar Energy for a Sustainable Future, Göteborg, Sweden, 14-19 June 2003.

11. Di Somma, M.; Yan, B.; Bianco, N.; Graditi, G.; Luh, P.B.; Mongibello, L.; Naso, V. Operation optimization of a distributed energy system considering energy costs and exergy efficiency. Energy Convers. Manag. 2015, 103, 739-751. [CrossRef]

12. Di Silvestre, M.L.; Graditi, G.; Sanseverino, E.R. A Generalized Framework for Optimal Sizing of Distributed Energy Resources in Micro-Grids Using an Indicator-Based Swarm Approach. IEEE Trans. Ind. Inform. 2014, 10, 152-162. [CrossRef]

13. Jiménez-Castillo, G.; Munoz-Rodriguez, F.J.; Rus-Casas, C.; Talavera, D.L. A new approach based on economic profitability to sizing the photovoltaic generator in self-consumption systems without storage. Renew. Energy 2020, 148, 1017-1033. [CrossRef]

14. Duić, N. Is the success of clean energy guaranteed? Clean Technol. Environ. Policy 2015, 17, 2093-2100. [CrossRef]

15. Cucchiella, F.; D'Adamo, I. A multicriteria analysis of photovoltaic systems: Energetic, environmental, and economic assessments. Int. J. Photoenergy 2015, 1, 1-8. [CrossRef]

16. Laleman, R.; Albrecht, J.; Dewulf, J. Life Cycle Analysis to estimate the environmental impact of residential photovoltaic systems in regions with a low solar irradiation. Renew. Sustain. Energy Rev. 2011, 15, 267-281. [CrossRef]

17. Mohammadi, K.; Khanmohammadi, S.; Khorasanizadeh, H.; Powell, K. Development of high concentration photovoltaics (HCPV) power plants in the US Southwest: Economic assessment and sensitivity analysis. Sustain. Energy Technol. Assess. 2020, $42,100873$. [CrossRef]

18. Talavera, D.L.; Perez-Higueras, P.; Almonacid, F.; Fernandez, E.F. A worldwide assessment of economic feasibility of HCPV powerplants: Profitability and competitiveness. Energy 2017, 119, 408-424. [CrossRef]

19. Mohammadi, K.; Naderi, M.; Saghafifar, M. Economic feasibility of developing grid-connected photovoltaic plants in the southern coast of Iran. Energy 2018, 156, 17-31. [CrossRef]

20. Abu-Rumman, A.K.; Muslih, I.; Barghash, M.A. Life Cycling Costing of PV Generation System. J. Appl. Res. Ind. Eng. 2017, $4,252-258$.

21. Jakhrani, A.Q.; Rigit, A.R.H.; Othman, A.; Samo, S.R.; Kamboh, S.A. Life cycle cost analysis of a standalone PV system. In Proceedings of the International Conference on Green and Ubiquitous Technology, Jakarta, Indonesia, 8-9 March 2012; pp. 82-85.

22. Khatib, T.; Muhsen, D.H. Optimal Sizing of Standalone Photovoltaic System Using Improved Performance Model and Optimization Algorithm. Sustainability 2020, 12, 2233. [CrossRef]

23. Manohar, K.; Ramkissoon, R.; Adeyanju, A. Cost Benefit Analysis of Implementing a Solar Photovoltaic System. Int. J. Innov. Res. Sci. Eng. Technol. 2015, 4, 11696-11703.

24. Ramadhan, M.; Naseeb, A. The cost benefit analysis of implementing photovoltaic solar systemin the state of Kuwait. Renew. Energy 2011, 36, 1272-1276. [CrossRef]

25. Cucchiella, F.; D'Adamo, I.; Gastaldi, M. A profitability assessment of small-scale photovoltaic systems in an electricity market without subsidies. Energy Convers. Manag. 2016, 129, 62-74. [CrossRef]

26. Cucchiella, F.; D'Adamo, I.; Gastaldi, M. Economic Analysis of a Photovoltaic System: A Resource for Residential Households. Energies 2017, 10, 814. [CrossRef]

27. Chiaroni, D.; Chiesa, V.; Colasanti, L.; Cucchiella, F.; D'Adamo, I.; Frattini, F. Evaluating solar energy profitability: A focus on the role of self-consumption. Energy Convers. Manag. 2014, 88, 317-331. [CrossRef]

28. Nassar-Eddine, I.; Obbadi, A.; Errami, Y.; El Fajri, A.; Agunaou, M. Parameter estimation of photovoltaic modules using iterative method and the Lambert W function: A comparative study. Energy Convers. Manag. 2016, 119, 37-48. [CrossRef]

29. Sánchez-Lozano, J.; García-Cascales, M.; Lamata, M. Comparative TOPSIS-ELECTRE TRI methods for optimal sites for photovoltaic solar farms. Case study in Spain. J. Clean. Prod. 2016, 127, 387-398. [CrossRef]

30. Bey, M.; Hamidat, A.; Benyoucef, B.; Nacer, T. Viability study of the use of grid connected photovoltaic system in agriculture: Case of Algerian dairy farms. Renew. Sustain. Energy Rev. 2016, 63, 333-345. [CrossRef]

31. Hassan, Q. Evaluation and optimization of off-grid and on-grid photovoltaic power system for typical household electrification. Renew. Energy 2021, 164, 375-390. [CrossRef]

32. Camilo, F.M.; Castro, R.; Almeida, M.E.; Fernão Pires, V. Economic assessment of residential PV systems with self-consumption and storage in Portugal. Sol. Energy 2017, 150, 353-362. [CrossRef]

33. Roldan Fernandez, J.M.; Burgos Payan, M.B.; Riquelme Santos, J.M. Profitability of household photovoltaic self-consumption in Spain. J. Clean. Prod. 2021, 279, 123439. [CrossRef]

34. Klugmann-Radziemska, E.; Rudnicka, M. The Analysis of Working Parameters Decrease in Photovoltaic Modules as a Result of Dust Deposition. Energies 2020, 13, 4138. [CrossRef]

35. Klugmann-Radziemska, E. Shading, Dusting and Incorrect Positioning of Photovoltaic Modules as Important Factors in Performance Reduction. Energies 2020, 13, 1992. [CrossRef]

36. Bukowski, M.; Majewski, J.; Sobolewska, A. Macroeconomic Electric Energy Production Efficiency of Photovoltaic Panels in Single-Family Homes in Poland. Energies 2021, 14, 126. [CrossRef]

37. Jurasz, J.; Wdowikowski, M.; Figurski, M. Simulating Power Generation from Photovoltaics in the Polish Power System Based on Ground Meteorological Measurements-First Tests Based on Transmission System Operator Data. Energies 2020, $13,4255$. [CrossRef] 
38. Małkowski, R.; Jaskólski, M.; Pawlicki, W. Operation of the Hybrid Photovoltaic-Battery System on the Electricity MarketSimulation. Real-Time Tests and Cost Analysis. Energies 2020, 13, 1402. [CrossRef]

39. Wajs, J.; Golabek, A.; Bochniak, R. Photovoltaic Roof Tiles: The Influence of Heat Recovery on Overall Performance. Energies 2019, 12, 4097. [CrossRef]

40. Kobashi, T.; Yarime, M. Techno-economic assessment of the residential photovoltaic systems integrated with electric vehicles: A case study of Japanese households towards 2030. Energy Procedia 2019, 158, 3802-3807. [CrossRef]

41. Dondariya, C.; Porwal, D.; Awasthi, A.; Shukla, A.K.; Sudhakar, K.; Manohar, S.R.; Bhimte, A. Performance simulation of grid-connected rooftop solar PV system for small households: A case study of Ujjain, India. Energy Rep. 2018, 4, 546-553. [CrossRef]

42. Dharshing, S. Household dynamics of technology adoption: A spatial econometric analysis of residential solar photovoltaic (PV) systems in Germany. Energy Res. Soc. Sci. 2017, 23, 113-124. [CrossRef]

43. Energy Market Information Center (CIRE). Available online: https://www.cire.pl/item,178198,2,0,0,1,0,0,oplacalnoscekonomiczna-farmy-fotowoltaicznej-do-1-mw-w-warunkach-polskich.html (accessed on 8 February 2021).

44. Olczak, P.; Olek, M.; Matuszewska, D.; Dyczko, A.; Mania, T. Monofacial and Bifacial Micro PV Installation as Element of Energy Transition-The Case of Poland. Energies 2021, 14, 499. [CrossRef]

45. Gong, X.; Kulkarni, M. Design optimization of a large scale rooftop photovoltaic system. Sol. Energy 2005, 78, 362-374. [CrossRef]

46. Soliński, B.; Kała, J. Economic cost-effectiveness of photovoltaic micro-installations used by prosumer. Probl. Small Agric. Hold. 2017, 4, 105-116.

47. Photovoltaic Geographical Information System. European Commission. Available online: https://re.jrc.ec.europa.eu/pvg_tools/ en/tools.html (accessed on 7 January 2021).

48. Available online: https://www.expertsure.com/uk/home/tools/solar-panel-calculator/ (accessed on 7 January 2021).

49. Available online: https://www.solar-nation.org/solar-power-calculator (accessed on 7 January 2021).

50. Brochocka, I.; Żaryczyński, A.; Zaborowski, M.; Rylski, A. Dobór i Zastosowanie Kalkulatora Fotowoltaicznego do Wstępnego Projektowania Instalacji Prosumenckich. Aura 2019, 290, 2-5.

51. Hewalex. Available online: http://www.hewalex.pl/fotowoltaika/kalkulator/ (accessed on 8 December 2020).

52. Lensolar. Available online: https://lensolar.pl/offer/calculator (accessed on 8 December 2020).

53. Pi-tern. Available online: http://www.pitern.pl/kalkulator-fotowoltaiczny (accessed on 8 December 2020).

54. Pro-sun. Available online: http:/ / www.pro-sun.pl/pv / (accessed on 8 December 2020).

55. Solsum. Available online: http://solsum.pl/klient-indywidualny/kalkulator-fotowoltaiczny/ (accessed on 8 December 2020).

56. Stiloenergy. Available online: http://stiloenergy.pl/kalkulator/\#/ (accessed on 9 December 2020).

57. Energy, R.E. Available online: https://energyre.pl/fotowoltaika-kalkulator-oplacalnosci/?gclid=EAlalQobChMlxuGAk_HJ3 QIVAqsYCh3H3Qy2EAAYASABEgLHMvD_BwE (accessed on 9 December 2020).

58. Electronic Devices Cezary Kuran. Available online: http://electronic-devices.pl/kalkulator-systemow-fotowoltaicznych,8/ (accessed on 9 December 2020).

59. Easysolar. Available online: http:/ / easysolar.pl/kalkulator\#oszcz\%C4\%99dno\%C5\%9B-ci (accessed on 10 December 2020).

60. Brewa Efektywna Energia, S.C. Available online: https://www.brewa.pl/panele-kalkulator-fotowoltaiczny.html?gclid= EAlalQobChMI6IHI6PLJ3QI-VzMqyCh13TA8HEAAYAiAAEgLm7fD_BwE (accessed on 10 December 2020).

61. BELOS-PLP, S.A. Available online: http:// www.belos-plp.com.pl/kalkulator-fotowoltaiczny (accessed on 10 December 2020).

62. The Act of 30 August 2019 amending the act on personal income tax and amending the act on personal income tax and certain other acts. J. Laws Pol. 2019, 1835, 1-3.

63. Wieprow, J. Ocena efektywności inwestycji rzeczowych za pomoca metody NPV. Zesz. Nauk. Wyższej Szkoły Bank. We Wrocławiu 2013, 6, 85-97.

64. Rynek Mikroinstalacji Fotowoltaicznych Polska'20. Stowarzyszenie Branży Fotowoltaicznej SBF POLSKA PV. Available online: http:/ / polskapv.pl (accessed on 17 February 2021).

65. Energy Consumption in Households in 2018. 2019 Statistics Poland. Available online: https:/ / stat.gov.pl (accessed on 18 February 2021).

66. Wójcicki, R. Solar Photovoltaic Self-consumption in the Polish Prosumer Sector. Rynek Energii 2020, 1, 11-17.

67. Wytyczne w zakresie zagadnień związanych z przygotowaniem projektów inwestycyjnych, w tym projektów generujących dochód i projektów hybrydowych na lata 2014-2020. MIiR/2014-2020/7(3), Minister Inwestycji i Rozwoju 2019. Available online: https:/ / www.funduszeeuropejskie.gov.pl (accessed on 18 February 2021). 